\title{
New Bis(thiosemicarbazonate) gold(III) complexes inhibit HIV replication at cytostatic concentrations: potential for incorporation into virostatic cocktails
}

\author{
Pascaline N. Fonteh ${ }^{\mathrm{a}}$, Frankline K. Keter ${ }^{\mathrm{a}, \mathrm{b}}$, Debra Meyer ${ }^{\mathrm{a}, *}$ \\ aDepartment of Biochemistry, University of Pretoria, Hatfield Campus, Pretoria 0002, South Africa \\ ${ }^{\mathrm{b}}$ Present address: Advanced Materials Division, Mintek, Private Bag X3015, Randburg 2125, South Africa \\ *Corresponding author: Debra.Meyer@up.ac.za, Tel: +27 12420 2300, \\ Fax: +27 123625302
}

\section{ABSTRACT}

Four bis(thiosemicarbazonate)gold(III) complexes (1-4) with a general formula $[\mathrm{Au}(\mathrm{L})] \mathrm{Cl}$ $\left\{\mathrm{L}=\mathrm{L1}\right.$, glyoxal-bis $\left(\mathrm{N}^{4}\right.$-methylthiosemicarbazone); L2, glyoxal-bis $\left(\mathrm{N}^{4}\right.$ -

ethylthiosemicarbazone); L3, diacetyl-bis( $\mathrm{N}^{4}$-methylthiosemicarbazone); L4, diacetylbis $\left(\mathrm{N}^{4}\right.$-ethylthiosemicarbazone $\left.)\right\}$ were synthesised and screened for activity against the human immunodeficiency virus (HIV). Complexes 1-4 were characterized using ${ }^{1} \mathrm{H}-\mathrm{NMR}$ and IR spectroscopy; and their purity established by micronanalysis. Complex 3 inhibited viral infection of TZM-bl cells by $98 \%\left(\mathrm{IC}_{50}=6.8 \pm 0.6 \mu \mathrm{M}\right)$ at a non toxic concentration of $12.5 \mu \mathrm{M}$ while complex 4 inhibited infection of these cells by 72 and $98 \%\left(\mathrm{IC}_{50}=5.3 \pm 0.4 \mu \mathrm{M}\right)$ at concentrations of 6.25 and $12.5 \mu \mathrm{M}$ respectively. The mechanism of inhibition of infection in TZM-bl cells is presumably as a result of the cytostatic or anti-proliferative activity that was observed for complex 4 in real time cell electronic sensing (RT-CES) and carboxyflourescein succinimidyl ester (CFSE) analysis. Treatment of T lymphocytes from HIV infected individuals with $\mathbf{4}$ decreased 
CD4+ T cell expression $(p=0.0049)$ as demonstrated by multi-parametric flow cytometry without suppressing cytokine production. None of the ligands (L1-L4) demonstrated anti-viral activity, supporting the importance of metal (gold) complexation in these potential drugs. Complexes $\mathbf{3}$ and $\mathbf{4}$ were shown to have ideal lipophilicity values that were similar when shake flask $(0.97 \pm 0.5$ and $2.42 \pm 0.6)$ and in silico prediction $(0.8$ and 1.5) methods were compared. The activity and drug-like properties of complexes 3 and 4 suggests that these novel metal-based compounds could be combined with virus inhibitory drugs to work as cytostatic agents in the emerging class of anti-HIV drugs known as virostatics.

Keywords: Bis(thiosemicarbazonate) gold(III) complexes, anti-HIV activity, immune effect, cytostasis.

\section{INTRODUCTION}

Highly active antiretroviral therapy (HAART) is successful in increasing the lifespan of human immunodeficiency virus (HIV) infected individuals but toxic side effects and the development of resistant viral strains could eventually render these drugs ineffective. When drug failure and or cross resistance to the same class of compounds occurs, treatment options become limited [1]. Identifying novel compounds which can be used in combination with HAART while maintaining a better resistance profile is therefore very important.

Gold-based drugs, very well known for rheumatoid arthritis (RA) treatment $[2,3]$, also demonstrate anti-HIV activity, reviewed by Fonteh et al., 2010 [4]. Ligands play a crucial role in the synthesis of gold-based compounds in that their complexation to metals not only gives rise to stable compounds, but in some cases leads to better activities and/or 
reduced toxicities [5]. Thiosemicarbazones (Tscs) and their related complexes possess medicinal value [6] including antiviral activity [7-9] and are examples of useful ligands in metal drug synthesis.

Gold(III) compounds are prone to biologically occurring reductants such as thiols which reduce them to gold(I) [2]. Stable gold(III) complexes with anti-HIV activity exist [10, 11], with their stability related to the ligand choice. The use of hard donor ligands such as $\mathrm{N}$ and $\mathrm{O}$ produces relatively stable gold(III) compounds. Tscs are compounds of mixed donor atoms (N, S) and their resultant gold(III) complexes are relatively stable in the biological milieu. Considering that Tscs-based compounds have shown anti-HIV activity $[7,12]$ coupled with the therapeutic nature of gold-based compounds, our aim was to synthesise and determine the anti-HIV activity of new gold(III) complexes of Tscs.

Gold(III) compounds are candidates for the treatment of cancers and micro-organism infections because of their selective cytotoxicity and cytostatic abilities. This cytostatic nature also explains a known anti-viral mechanism of action making them candidate anti-HIV agents. Cytostatic drugs exert their effect on infected host cells rather than on the invading pathogen and must therefore be used in combination with a directly antiviral agent for maximum effect. The best known cytostatic (anti-proliferative) agent in HIV research, hydroxyurea (HU) has been shown to inhibit HIV-1 replication at optimal concentrations [13] but also lowered CD4+ cell numbers [14-16]. At first, this may appear counter-productive for an HIVIAIDS treatment, but since HIV replication occurs in actively dividing cells $[17,18]$, this lowering of CD4 cells is one of the ways in which HU exerts its anti-HIV activity (by restricting the numbers of activated or bystander cells primed for killing by HIV). HU in combination with didanosine results in a synergistic, increased anti-viral potency and a better resistance profile [19]. In addition, HU and 
didanosine boosts immune parameters including increases in CD4+ cell count [20]. The HU-didanosine combination decreases deoxyribonucleotides (dNTPs) resulting in an increase in the dNTP analogue (didanosine) which is a nucleotide reverse transcriptase inhibitor resulting in an increase in anti-HIV activity $[21,22]$. The combination of cytostatic drugs with anti-viral agents, results in an overall significantly beneficial antiHIV effect $[13,19,20,23,24]$. Lori and colleagues $[13,19]$ named this combination virostatics and defined it as a class of emerging anti-HIV agents which are characterised by the combination of a drug directly inhibiting virus production (viro) e.g. didanosine and one indirectly inhibiting virus replication by reducing cellular proliferation (static) e.g. HU.

The current approach of HIV medicine (HAART) is aimed at the reduction in viral load and prevention of further loss of CD4+ cells [19]. However, viral resistance (also observed for the recently approved integrase inhibitors [25]) is still a major concern when using combinations that directly target the virus. The advantage incurred from having a drug that results in an overall better resistance profile like HU in the HUdidanosine combination is arguably a better option than combinations for which resistance could easily become a problem rendering them obsolete. This is because HU's antiviral activity is linked to the inhibition of a cellular enzyme (ribonucleotide reductase or RNR) which is not prone to the same resistance concerns as viral enzymes [26].

This paper is a documentation of the synthesis and characterisation of complexes 1-4 and investigation of their possible anti-HIV mechanism of action. Findings presented suggest a cytostatic mechanism of inhibition of viral infectivity by two of the tested complexes ( $\mathbf{3}$ and $\mathbf{4}$ ). The cytostatic nature of the gold Tscs compounds $\mathbf{3}$ and $\mathbf{4}$ 
reported here, and their observed anti-viral activity supports their potential for incorporation in virostatic cocktails.

\section{MATERIALS AND METHODS}

\subsection{Reagents, Starting Materials and Instrumentation}

Gold starting material, $\mathrm{HAuCl}_{4} .4 \mathrm{H}_{2} \mathrm{O}$, was synthesised using procedures reported by Block, 1953 [27] and bis(thiosemicarbazone) ligands (L1-L4) according to methods by West et al., 1997 [28]. All the solvents were purchased from Merck and dried using conventional methods. Ligands L1-L4 and complexes 1-4 (collectively referred to as the compounds from here onwards) were prepared under dry, deoxygenated nitrogen atmosphere using Schlenk techniques. IR spectra were recorded as $\mathrm{KBr}$ pellets on a Perkin-Elmer, paragon 1000 PC FTIR spectrophotometer. ${ }^{1} \mathrm{H}-\mathrm{NMR}$ spectra were recorded on a Bruker Avance DPX spectrometer $\left({ }^{1} \mathrm{H}, 500 \mathrm{MHz}\right)$ in DMSO-d6 and $\mathrm{D}_{2} \mathrm{O}$. ${ }^{1} \mathrm{H}$ chemical shifts of the compounds were referenced to the signals of the residual proton peaks of the NMR solvents and quoted in ppm. The splitting of proton resonances in the reported ${ }^{1} \mathrm{H}$ NMR spectra are defined as $\mathrm{s}=$ singlet, bs $=$ broad singlet, $\mathrm{q}=$ quartet and $\mathrm{m}=$ multiplet.

\subsection{Synthesis and Complexation}

\subsubsection{Synthesis of glyoxal-bis $\left(\mathrm{N}^{4}\right.$-methylthiosemicarbazonate)gold(III)chloride (1)}

Ligand L1 $(0.12 \mathrm{~g}, 0.54 \mathrm{mmol})$ was added to an ethanol solution $(20 \mathrm{~mL})$ of $\mathrm{HAuCl}_{4} .4 \mathrm{H}_{2} \mathrm{O}(0.22 \mathrm{~g}, 0.54 \mathrm{mmol})$ leading to the formation of a brown suspension. The reaction was left to stir for $1.5 \mathrm{~h}$ during which time the suspension turned from brown to a wine-red solution. The reaction was stopped, solvent reduced in vacuo and a brown- 
green precipitate isolated as the product (1). Yield $=0.17 \mathrm{~g}(62 \%) .{ }^{1} \mathrm{H}$ NMR: (DMSOd6): $\delta 8.85$ (bs, $2 \mathrm{H}, \mathrm{CH}_{3} \underline{\mathrm{N}}$ ); 7.87 (s, 2H, $\left.\underline{\mathrm{H}}-\mathrm{C}=\mathrm{N}\right) ; 3.02$ (s, 6H, $\left.\underline{\mathrm{H}}_{3}\right)$. FTIR: $\left(\mathrm{KBr}, \mathrm{cm}^{-1}\right)$ : $U_{N-H(R N H)}=3137, U_{C=N}=1572$. Anal. Calc. for $C_{6} H_{10} A u C I N_{6} S_{2}: C, 15.57 ; H, 2.18 ; N$, 18.16; S, 13.86\%. Found: C, 16.01; H, 2.51; N, 18.54; S, 14.28\%.

\subsubsection{Synthesis of glyoxal-bis( $\mathrm{N}^{4}$-ethylthiosemicarbazonate)gold(III)chloride (2)}

This complex was synthesised in a similar manner to that of $1(2.2 .1)$; $\mathbf{L} 2(0.13 \mathrm{~g}, 0.49$ mmol) was added to an ethanol solution of $\mathrm{HAuCl}_{4} .4 \mathrm{H}_{2} \mathrm{O}(0.2 \mathrm{~g}, 0.49 \mathrm{mmol})$. The product (2) was isolated as greenish-brown solids. Yield $=0.15 \mathrm{~g}(59 \%) .{ }^{1} \mathrm{H}$ NMR: (DMSO-d6): $\delta 9.01$ (bs, 2H, $\mathrm{CH}_{3} \mathrm{~N} \underline{\mathrm{H}}$ ); 7.85 (s, 2H, $\underline{\mathrm{H}}-\mathrm{C}=\mathrm{N}$ ); 3.56 (q, 4H, $\left.\underline{\mathrm{H}}_{2} \mathrm{CH}_{3}\right) ; 1.16$ $\left(\mathrm{m}, 6 \mathrm{H}, \mathrm{CH}_{2} \underline{\mathrm{C}}_{3}\right)$. FTIR: $\left(\mathrm{KBr}, \mathrm{cm}^{-1}\right): U_{\mathrm{N}-\mathrm{H}(\mathrm{RNH})}=3122, U_{\mathrm{C}=\mathrm{N}}=1565$. Anal. Calc. for $\mathrm{C}_{6} \mathrm{H}_{14} \mathrm{AuCIN}_{6} \mathrm{~S}_{2}: \mathrm{C}, 19.58 ; \mathrm{H}, 2.88 ; \mathrm{N}, 17.12 ; \mathrm{S}, 13.07 \%$. Found: C, 19.89; H, 3.03; N, 16.94; S, $13.09 \%$.

2.2.3 Synthesis of diacetyl-bis( $\mathrm{N}^{4}$-methylthiosemicarbazonate)gold(III)chloride (3)

Complex 3 was synthesised in a similar manner to that 1 (2.2.1); $\mathbf{L} 3(0.06 \mathrm{~g}, 0.24 \mathrm{mmol})$ was added to an ethanol solution of $\mathrm{HAuCl}_{4} .4 \mathrm{H}_{2} \mathrm{O}(0.1 \mathrm{~g}, 0.24 \mathrm{mmol})$. The product (3) was isolated as dark-red solids. Yield $=0.08 \mathrm{~g}(67 \%) .{ }^{1} \mathrm{H}$ NMR: $\left(\mathrm{D}_{2} \mathrm{O}\right): \delta 8.33(\mathrm{~m}, 2 \mathrm{H}$, $\left.\mathrm{CH}_{3} \mathrm{~N} \underline{\mathrm{H}}\right) ; 3.06\left(\mathrm{~s}, 3 \mathrm{H}, \underline{\mathrm{C}}_{3}-\mathrm{C}=\mathrm{N}\right) ; 3.00\left(\mathrm{~s}, 3 \mathrm{H}, \underline{\mathrm{C}}_{3}-\mathrm{C}=\mathrm{N}\right) ; 2.20$ (s, 6H, $\left.\underline{\mathrm{H}}_{3}\right) . \mathrm{FTIR}:(\mathrm{KBr}$, $\left.\mathrm{cm}^{-1}\right): U_{N-H(R N H)}=3219, U_{C=N}=1663$. Anal. Calc. for $\mathrm{C}_{8} \mathrm{H}_{14} \mathrm{AuCIN}_{6} \mathrm{~S}_{2}: \mathrm{C}, 19.58 ; \mathrm{H}, 2.88$; N, 17.12; S, 13.07\%. Found: C, 19.27; H, 3.08; N, 17.07; S, 12.73\%. 
2.2.4 Synthesis of diacetyl-bis $\left(\mathrm{N}^{4}\right.$-ethylthiosemicarbazonate $)$ gold(III)chloride (4)

This complex was synthesised in a similar manner to that of $1(2.2 .1)$; $\mathbf{L} 4(0.07 \mathrm{~g}, 0.24$ mmol) was added to an ethanol solution of $\mathrm{HAuCl}_{4} \cdot 4 \mathrm{H}_{2} \mathrm{O}(0.1 \mathrm{~g}, 0.24 \mathrm{mmol})$. The product (4) was isolated as dark-red solids, $(0.1 \mathrm{~g}, 0.19 \mathrm{mmol}, 79 \%) .{ }^{1} \mathrm{H}$ NMR: $\left(\mathrm{D}_{2} \mathrm{O}\right): \delta$ $8.39\left(\mathrm{~m}, 2 \mathrm{H}, \mathrm{CH}_{3} \mathrm{~N} \underline{\mathrm{H}}\right) ; 3.49$ (q, 4H, $\left.\mathrm{CH}_{2} \mathrm{CH}_{3}\right) ; 2.31\left(\mathrm{~s}, 6 \mathrm{H}, \mathrm{C}_{3}-\mathrm{C}=\mathrm{N}\right) ; 1.13(\mathrm{~m}, 6 \mathrm{H}$, $\left.\mathrm{CH}_{2} \mathrm{C}_{3}\right)$. FTIR: $\left(\mathrm{KBr}, \mathrm{cm}^{-1}\right): U_{\mathrm{N}-\mathrm{H}(\mathrm{RNH})}=3148, U_{\mathrm{C}=\mathrm{N}}=1688$. Anal. Calc. for $\mathrm{C}_{10} \mathrm{H}_{18} \mathrm{AuCIN}_{6} \mathrm{~S}_{2}: \mathrm{C}, 23.15 ; \mathrm{H}, 3.50 ; \mathrm{N}, 16.20 ; \mathrm{S}, 12.36 \%$. Found: C, 23.47; H, 3.58; N, $16.08 ; \mathrm{S}, 12.14 \%$.

2.3 Effect of the Complexes on Viral Infectivity, Viability and Proliferation

The TZM-bl cell line is a HeLa clone that was engineered to express CD4, chemokine receptor (CCR)5 and CXC chemokine receptor (CXCR)4 and contains an integrated reporter gene for $\beta$ galactosidase and luciferase under the control of an HIV-1 long terminal repeat [29]. This cell line was used for infectivity determination and the assay was performed at the laboratory of Prof. Lynn Morris at the National Institute of Communicable Diseases (NICD, South Africa) according to the protocol described by David Montefiori in 2004 [30]. Du151.2, an isolate of two phylogenetically distinct subtype C strains [31], at a dilution that gave $50,000 \pm 15000$ relative light units (tissue culture infectious dose - TCID) was pre-treated with complexes 1-4 for $1 \mathrm{~h}$ followed by the addition of $100 \mu \mathrm{L}$ of cells $\left(1 \times 10^{5}\right.$ cells $\left./ \mathrm{mL}\right)$ to a final volume of $250 \mu \mathrm{L}$. Luciferase activity was measured after $48 \mathrm{~h}$ using the bright glo substrate solution (Promega, Wisconsin, USA). Infectivity inhibition was determined as a percentage using the 
formula $=100-[($ test wells-CC $) /(\mathrm{VC}-\mathrm{CC})] \times 100$, where $\mathrm{CC}=$ cell control and $\mathrm{VC}=$ virus control.

Considering that infectivity data can be influenced by cell death, cell viability experiments were performed at the same concentrations of 1-4 used in the infectivity assay to ensure that any observed signals as a result of luciferase activity did not stem from the fact that cell viability had been compromised. This was done using 3-(4,5dimethylthiazol-2-yl)-2,5-diphenyltetrazolium bromide (MTT). TZM-bl cells (1x10 cells $/ \mathrm{mL}$ ) in complete DMEM medium (containing antibiotics and fetal calf serum) were treated with various concentrations of the compounds $(0.2-25 \mu \mathrm{M})$ in cell culture grade 96 well plates and incubated $\left(37^{\circ} \mathrm{C}, 95 \%\right.$ humidity, $\left.5 \% \mathrm{CO}_{2}\right)$ for $48 \mathrm{~h}$. At the end of the incubation, $150 \mu \mathrm{L}$ spent medium was discarded and replaced with $150 \mu \mathrm{L}$ freshly prepared complete medium. Twenty microlitres of MTT $(5 \mathrm{mg} / \mathrm{mL})$ was added to the cells, and within $2 \mathrm{~h}$, colour development was enhanced by solubilisation of formazan crystals formed as a result of reduction of MTT tetrazolium compound by dehydrogenases in viable cells. The plates were read at $550 \mathrm{~nm}$ (reference wavelength of $690 \mathrm{~nm}$ ). Viability percentages were determined relative to an untreated control of cells only.

In addition to using MTT for viability analysis, a real time-cell electronic sensing (RTCES) device, xCELLigence (Roche Diagnostics, Mannheim, Germany) was used to monitor proliferation of the TZM-bl cells in the presence of L4 and $\mathbf{4}$. The system uses a 96 well plate (E-plate) which contains integral sensor electrode arrays that allow cells (adherent only) within each well to be monitored. The presence of cells in the wells of the E-plate affects the local environment leading to an increase in electronic impedence as the cells adhere. The more the cells attach to the electrodes, the higher the electronic 
impedence which is read as cell index $(\mathrm{Cl})$. This assay has been described for the measurement of cytotoxicity [32-34] and can be used to determine other cellular parameters such as cell proliferation, cytotoxicity start time, cell recovery and cell response patterns [34] in real time. Three different concentrations $(0.1,5$ and $10 \mu \mathrm{M})$ of L4 and 4 were tested alongside $10 \mu \mathrm{M}$ auranofin (an anti-arthritic gold-based compound which has been shown to have both anti-tumour and anti-HIV activity) as a positive control for toxicity. A background control (media only) and a vehicle (DMSO) control were also included. The cells were first allowed to adhere to the E-plate and after $20 \mathrm{~h}$ (and about $80 \%$ confluency), L4 and $\mathbf{4}$ were added and the adherence of the cells monitored for a further 2, 5 or 7 days. Cells could exhibit varying response patterns represented by $\mathrm{Cl}$ changes which could either be proliferating (increasing $\mathrm{Cl}$ ), cytotoxic (decreasing $\mathrm{Cl}$ ) or cytostatic (stable $\mathrm{Cl}$ ).

\subsection{Effect of the Compounds on Immune Cell Proliferation and Function}

To investigate whether the compounds had an effect on immune system cell function (CD4+ and CD8+ lymphocytes) which in turn could be associated with the antiviral or cytostatic activity observed, cell proliferation and the production of a key proinflammatory cytokine, tumour necrosis factor alpha (TNF- $\alpha$ ) and an anti-inflammatory cytokine, interferon gamma (IFN-ү) were monitored using multi-parametric flow cytometry. These studies were performed on peripheral blood mononuclear cells (PBMCs) from HIV infected individuals. Ethical Clearance for obtaining blood samples from consenting donors was obtained from the Faculties of Natural and Agricultural Sciences and Health Sciences Ethics Committees (University of Pretoria, South Africa). 
PBMCs were isolated by density gradient centrifugation using lymphocyte separation medium (Cambrex BioScience, Maryland, USA). The carboxyflourescein succinimidyl ester (CFSE, Molecular Probes, Oregon, USA) dye was used for monitoring proliferation from a "live gate" by incorporating propidium iodide (PI) which helps to exclude background staining from dead cells. CFSE is a cell proliferation dye that binds spontaneously and irreversibly couples to cellular proteins by reaction with lysine side chains and other available amines [35]. As the cells divide, the intensity of the dye is spread between daughter cells allowing for proliferation monitoring by flow cytometry. CFSE labelled PBMCs stimulated with phytohemagglutinin-protein (PHA-P, $2 \mu \mathrm{g} / \mathrm{ml}$ ) were treated with various concentrations $(0.2-5 \mu \mathrm{M}$, these are concentrations that resulted in $>60 \%$ viability in a high throughput dye assay, data not shown) of the compounds for $72 \mathrm{~h}$. The cells were resuspended in staining buffer and stained with a pre-titrated amount of PI (Becton Dickinson-BD BioSciences, California, USA) for 15 min. Data (10, 000 events) was acquired on a FACSAria (BD BioSciences, California, USA) within $30 \mathrm{~min}$ and analysed using FlowJo Version 7.6.1 (TreeStar Inc., Oregon, USA).

To investigate the effect of the compounds on T cell expression and cytokine production, PBMCs ( $1 \times 10^{6}$ cells) from 12 consenting HIV+ individuals were incubated at $37{ }^{\circ} \mathrm{C}$ under $5 \% \mathrm{CO}_{2}$ with or without the compounds $(0.2-5 \mu \mathrm{M})$ to a final volume of 200 uL in V-shaped 96 well tissue culture plates. After $18 \mathrm{~h}$, stimulants consisting of 10 $\mathrm{ng} / \mathrm{mL}$ of phorbol myristate acetate and $1 \mu \mathrm{M}$ of ionomycin were added to the cells alongside $1 \mu \mathrm{L}$ of protein transport inhibitor containing brefeldin A (golgistop) which prevents cytokines from being secreted (all from BD BioSciences, California, USA). The cells were harvested after a further $6 \mathrm{~h}$ incubation period by washing with staining buffer 
(phosphate buffered saline, $\mathrm{pH}$ 7.4) followed by staining for surface markers using monoclonal antibodies for cell surface receptors: CD3-pacific blue, CD4- phycoerythrin (PE), CD8-peridinin chlorophyll protein-cyanin (PerCP-Cy)5.5 and an aqua fluorescent fixable amine reactive dye (Molecular Probes, Oregon, USA) for "live gating". After permeabilisation and fixation with cytofix/cytoperm solution (BD BioSciences, California, USA), intracellular staining with human cytokine monoclonal antibodies consisting of anti-TNF-a-allophycocyanin (APC) and IFN- $\gamma$-flourescein isothiocyanate (FITC) all from Pharmingen (BD BioSciences, California, USA) was performed. The samples were resuspended in 3\% (v/v) formaldehyde and 30,000 events were collected using a FACSAria flow cytometer (BD BioSciences, California, USA). Data analysis was done using FlowJo Version 7.6.1(TreeStar Inc., Oregon, USA) while statistical analysis was done using Graphpad Prism (Graphpad Software Inc. California, USA). The Wilcoxon matched-pairs signed rank test was used in determining statistical significance between medians with a one way nonparametric statistical test used since the data did not meet normal distribution. Correlations were tested using the non parametric Spearman correlation test. A p value of $<0.05$ was considered significant.

\subsection{Lipophilicity Determination}

The shake flask method and in silico prediction using the Absorption, Distribution, Metabolism, Excretion and Toxicity $(A D M E T)$ protocol in Discovery studio (DS $\left.{ }^{\circledR}\right)$ Client 2.5.5 (Accelrys $\AA$, California, USA) were employed in determining the lipophilicity of the complexes.

A modification of the shake flask method by Yousif et al., 2009 [36] was performed. Phosphate buffered saline (PBS, sterile filtered, $\mathrm{pH} 7.4$ ) was used as the aqueous 
phase while the organic phase was 1-octanol (Sigma Aldrich, Missouri, USA).

Complexes $\mathbf{3}$ and $\mathbf{4}$ were dissolved in DMSO and diluted with PBS to a final concentration of $200 \mu \mathrm{M}$. This was followed by the addition of an equal volume of 1octanol and the solutions subjected to 30 min of shaking (45 rpm) using an Intelli Mixer (Sky Line, Riga, Latvia) to attain equilibrium. Atomic absorbance of both phases was obtained at $365 \mathrm{~nm}$. Known concentrations of the samples in both solvents were used as standards in determining that of the test samples. Log P (lipophilicity) was defined and calculated as the logarithm of the ratio of the concentrations of the complex in the organic and aqueous phases $\left(\log P=\log \left\{\left[\operatorname{compound}_{(\text {org })}\right] /\left[\operatorname{compound}_{(\mathrm{aq})}\right]\right\}\right.$ where org=organic phase and aq=aqueous phase.

In the in silico prediction studies in $\mathrm{DS}^{\circledR}$, the molecular structure of the compounds in the structural data file (sdf) format were geometrically optimised and subjected to an ADMET run. A detailed protocol (found with the supplementary material after Fig. S2) includes various models for lipophilicity (atom based log P- AlogP98), human intestinal absorption, aqueous solubility, blood brain barrier penetration, cytochrome P450, hepatotoxicity and plasma protein binding predictions.

\section{RESULTS AND DISCUSSION}

3.1 Bis(thiosemicarbazonate) Gold(III) Complexes (1-4); Synthesis and Characterisation Reaction of bis(thiosemicarbazone) ligands with $\mathrm{HAuCl}_{4} .4 \mathrm{H}_{2} \mathrm{O}$ gave complexes of the general formula $[\mathrm{Au}(\mathrm{L})] \mathrm{Cl}_{3}\{\mathrm{~L}=\mathrm{L1}(1), \mathrm{L2}(2), \mathrm{L3}(3), \mathrm{L4}(4)\}$ (Fig. 1). The ${ }^{1} \mathrm{H}$ NMR (Table S1) and IR spectroscopic data analysis shows similarities in their structures. Complexes 1 and $\mathbf{2}$ were isolated as green-brown solids, while $\mathbf{3}$ and $\mathbf{4}$ were dark-red solids obtained in moderate yields. In the ${ }^{1} \mathrm{H}$ NMR spectral data of the complexes, the proton 
peaks at ca. $10 \mathrm{ppm}(\mathrm{C}=\mathrm{N}-\mathrm{N}-\underline{\mathrm{H}})$ were evidently absent in contrast to the ${ }^{1} \mathrm{H}$ NMR spectra of the respective ligands. This suggests that deprotonation of the ligands occurred during complexation. From the IR data acquired, the peaks due to $\left(U\left(\mathrm{~N}-\mathrm{H}_{\mathrm{C}=\mathrm{N}-\mathrm{N}-}\right.\right.$ H)) in the spectra of ligands L1-L4 (ca. $3350 \mathrm{~cm}^{-1}$ ) were absent in the spectra of 1-4. This further corroborates the deprotonation mentioned above. In addition, the disappearance of the $u(C=S)$ Thioamide IV vibration band at ca. $855 \mathrm{~cm}^{-1}$ in the IR spectra of 1-4 signifies reduction in the double bond character due to ligand coordination to the gold(III) ion. This further suggests that L1-L4 coordinate to gold in their thiolate forms. The purity of 1-4 was checked by microanalysis and the results presented in sections 2.2.1-2.2.4. Bottenus et al., 2010 [37] recently reported the synthesis of complex 3 which was prepared through a different synthetic protocol than that described here.

\section{Fig. 1}

Single crystals of 4 (as a representative compound) were grown from ethanol solutions and the structure elucidated (Fig. 2). However, the crystallographic data acquired was indicative of poor quality crystals. This is discernible from the $\mathrm{R}$ factor of $7.26 \%$ and the poor atomic displacement parameters (ellipsoids). Attempts made to re-grow the crystals gave the same results. Crystallographic data are therefore not discussed in full but are presented as supplementary material along with the bond lengths and angles (Table S2a and S2b). The structure (Fig. 2) is presented to show that the connectivity and coordination of the bis(thiosemicarbazones) to gold(III) is through two iminic nitrogen atoms and two sulfur atoms. The complex was isolated as a salt with a chloride as the counterion. 
Fig. 2

3.2 Effect of the complexes 1-4 on viral infectivity and viability of the TZM-bl cell line.

Inhibition of Du 151.2's infectivity by complexes 1-4 was measured as a reduction in luciferase reporter gene expression after a single round of infection of TZM-bl cells. There was a dose dependent decrease in infection from 0.2 to $25 \mu \mathrm{M}$ (Fig. 3). Viability was assessed (using MTT) to determine whether the inhibition observed was specific and not due to complex-initiated cell death. MTT viability data suggests that what appeared to be inhibition was a result of cell death, except in the case of $\mathbf{3}$ where at $12.5 \mu \mathrm{M}$, there was a $98 \%$ inhibition of infection while the cells were $67 \%$ viable (Fig. 3 ). The $I_{50}$ value of 3 against DU151.2's infection of the TZM-bl cell line was $6.8 \pm 0.6 \mu \mathrm{M}$ while that of 4 was $5.3 \pm 0.4 \mu \mathrm{M}$. These concentrations are known to be physiologically relevant for gold compounds. Complexes $\mathbf{1}$ and $\mathbf{2}$ were less specific than $\mathbf{3}$ and $\mathbf{4}$ as the inhibitory concentrations were also very toxic (Fig. 3). The ligands (L3 and L4) and gold starting material $\mathrm{HAuCl}_{4} .4 \mathrm{H}_{2} \mathrm{O}$ did not show any appreciable inhibition of Du151.2's infectivity. As a positive control for infectivity inhibition, a neutralising antibody control (designated Bb-pool) was used which always presented a dose response inhibition.

To verify whether inhibition of infection by $\mathbf{3}$ and $\mathbf{4}$ was through interaction with components on the surface of the virus (since the virus was pre-treated with the compounds), time of addition studies were performed for 3 and $\mathbf{4}$. The cells were pretreated with the compounds prior to addition of virus and the rest of the assay performed as previously described (2.3). The $\mathrm{IC}_{50}$ values obtained $(6.2 \pm 0.5$ and $6.0 \pm 1.3$ respectively) were not significantly different from when virus was pre-treated with compounds $(6.8 \pm 0.6$ and $5.3 \pm 0.4)$. This finding suggests that inhibition of infectivity was 
not imposed primarily on viral surface components but could have been as a result of the compounds effect on viral targets either within the cell or on its surface thus indirectly limiting infectivity. The main variable in this time of addition studies was the exposure time.

Fig. 3

When the RT-CES device (which monitors cell response patterns in real time) was used for proliferation and viability assessment, an interesting observation was made for complex 4 indicating that the compound was cytostatic rather than cytotoxic at 5 and 10 $\mu \mathrm{M}$ (Fig. 4a). Compared to $10 \mu \mathrm{M}$ of auranofin which killed the TZM-bl cells after 10 to $20 \mathrm{~h}$ of addition (Fig. 4a), cells treated with 4 initially underwent an uptake phase and then maintained a dose dependent cytostasis for the duration of the experiment (Fig. 4a). The inhibition of infectivity results for complex 4 at 6.25 and $12.5 \mu \mathrm{M}$ were 72 and $98 \%$ respectively (Fig. 3$)$. The MTT assay suggests toxicity at 6.25 (48.5\% viability) and $12.5 \mu \mathrm{M}(42.8 \%$ viability) for complex 4 (Fig. 3) but the RT-CES data demonstrates the compound's cytostatic effect (Fig. 4a). The viability of cells exposed to $10 \mu \mathrm{M}$ of auranofin (control for cell death) was $20 \%\left(\mathrm{CC}_{50}=5 \pm 0.8 \mu \mathrm{M}\right)$ also confirming the RT-CES findings for this compound. Data collected with the RT-CES assay is more reliable because it is not prone to the shortcomings of the MTT assay such as sensitivity to environmental conditions and dependence on the cells' metabolism of formazan, [38, 39]. Complex 4 may therefore have viral inhibitory activity through a cytostatic mechanism, a finding which has been reported for other anti-HIV agents such as HU $[13,19,20,23]$. Lori et al., in 2005 [13] showed that a cytostatic $10 \mu \mathrm{M}$ concentration of HU inhibited cell proliferation and suppressed HIV-1 replication in vitro. In a virostatic combination with didanosine, the indirect antiviral effect of $\mathrm{HU}$ and the direct antiviral 
effect of didanosine resulted in an overall beneficial effect $[13,19,20,23,24]$. On its own, compound $\mathbf{4}$ exhibited antiviral activity (lowering infectivity of TZM-bl cells by Du 151.2). Considering that cytostatic anti-viral activity is not ideal in the treatment of HIV (because it lowers CD4 counts), 4 would have to be combined with an anti-viral agent like didanosine in a virostatics cocktail just as in the HU-didanosine combination. In addition, because the anti-viral activity of other Tscs have been postulated [8] and shown [40] to be through the lowering of dNTP pools by inhibition of RNR we postulate that the antiviral activity of $\mathbf{4}$ (a gold(III) Tscs compound) is probably as a result of its inhibition of this enzyme as well.

Supporting data on this cytostatic tendency of $\mathbf{4}$ is provided in Fig. $\mathbf{S 1}$ (experimental repeats using RT-CES). In all cases the ligand, L4 did not show any significant cytostatic activity (Fig 4b, Fig. S1) compared to its complementary complex, 4, suggesting that the activity observed for 4 was as a result of complexation of L4 with gold.

Fig. 4

3.3 Effect of the compounds on immune cell proliferation and function

The cytostatic nature of 4 as well as 3 at $5 \mu \mathrm{M}$ was also observed in PHA-P stimulated PBMCs using the CFSE dye (Fig. 5). The intensity of the CFSE dye divided between daughter cells was monitored by flow cytometry and six different generations of dividing cells are represented. Complex 3 and $\mathbf{4}$ have the highest percentage of cells in the $1^{\text {st }}$ generation and no cells in the $6^{\text {th }}$ generation (Fig. 5). This implies that the majority of cells did not divide or proliferate past the $1^{\text {st }}$ generation compared to untreated cells and cells treated with L3 and L4. Cells treated with 1 and $\mathbf{2}$ proliferated more than those 
treated with 3 and $\mathbf{4}$ but not as much as the control. This data further affirms the cytostatic nature of complex 4 . It also shows complex 3 as being cytostatic. The complexes appear to exert their cytostatic effect irrespective of cell type i.e. primary immune system cells (PBMCs) or continuous cell line (TZM-bl cells). Ligands L3 and L4 did not affect cell proliferation further confirming findings from RT-CES analysis for L4. The CFSE data for $\mathbf{3}$ and $\mathbf{4}$ as well as the RT-CES analysis of $\mathbf{4}$ attest to the fact that these compounds have cytostatic tendencies. This further supports the absence of a direct anti-viral effect as seen from the time of addition studies suggesting that a cellular and not a viral target was involved. The CFSE data supports RT-CES (cytostasis) rather than MTT (cytotoxicity) data.

\section{Fig. 5}

To investigate whether the compounds have an effect on immune system cell activity which may further support their ability to suppress HIV replication, PBMCs from 12 treatment-naïve, HIV infected individuals were treated with L2, L4, 2 and $\mathbf{4}$ and their effects monitored using multi-parametric flow cytometry. Compound $\mathbf{4}$ caused a significant $(p=0.0049)$ decrease in the CD4+ cell expression (Fig. 6). The same compound did not have a significant effect on CD4+ cells production of TNF- $\alpha$ and IFN$Y$ (Fig. S2b and c) but its ligand (L4) increased TNF-a production with a significant $p$ value of 0.04 (Fig. S2c). TNF- $\alpha$ is a pro-inflammatory cytokine and by enhancing its secretion, L4 could help in driving pathogenesis. This is because TNF- $\alpha$ increase has been associated with HIV disease progression in vivo [41]. This effect appears to be diminished in 4 as a result of complexation with gold making 4 a better drug candidate. CD8+ cell expression was not altered for either L2, L4, 2 or $\mathbf{4}$ treated cells (Fig. S2d) and no significant effect on TNF- $\alpha$ and IFN-Y production was seen for any of these 
treatments (Fig. S2e and f). HU has been reported to exert a cytostatic but not an immunosuppressive effect on T lymphocytes by not decreasing the production of $\mathrm{T}$ helper (h)1 or Th2 cytokines [42]. In our experience 4 did not affect TNF- $\alpha$ and IFN-Y (both Th1 cytokines) production. Compound 4 like HU affects the immune system with respect to its cytostatic effect on CD4+ T lymphocytes but when measuring intracellular cytokine levels 4 had no effect on cytokine production by CD4+ and CD8+ cells.

Concerns regarding compounds like HU which suppress CD4+ cell expression and limit HIV infectivity through a cytostatic mechanism have been raised since these cells are needed by immunocompromised individuals. Several clinical trials e.g. the Research Institute for Genetic and Human Therapy (RIGHT) 411 trial [14], the AIDS Clinical Trials Group (ACTG) 307 study [15], the Swiss HIV Study cohort [16] and the Bristol-Myers Squibb (BMS) 055 study (Federici et al., hydroxyurea in combination regimens for the treatment of antiretroviral naïve, HIV- infected adults. XII International Conference on AIDS. Geneva, June 1998, abstract 287/12235) that used an optimal cytostatic dose of $\mathrm{HU}$ in combination with anti-viral agents such as didanosine showed superior efficacy over trial groups that did not incorporate it [13]. The explanation for this is that, when a compound suppresses the activity of CD4+ cells, it is likely that activated (antigen presenting) and bystander cells (which are mostly affected by HIV apoptosis [43] are reduced such that these cells are not primed for killing by HIV leading to an overall steady state that is beneficial to the host. Such treatment strategies are encouraged as first-line combinations to reduce the emergence of resistant strains and at a point when the patients are asymptomatic so as to avoid complications that could arise in advance disease [26].

Fig. 6 
We therefore suggest that compound $\mathbf{4}$ (and possibly $\mathbf{3}$ ) has antiviral activity as a result of its cytostatic and suppressive effect on immune activation and that if combined at the right dose with an anti-HIV agent e.g. didanosine, should prove promising in the combination therapy known as virostatics. Such a strategy of fighting HIV represents a novel approach of targeting HIV from multiple directions [20] with the most significant benefit being a better resistant profile.

\subsection{Lipophilicity studies}

Lipophilicity (Log P or AlogP98) is used to assess biological parameters relevant to drug action such as lipid solubility, tissue distribution, receptor binding, cellular uptake, metabolism and bioavailability [44]. As an important physicochemical property in drug design it plays a major role in the ADMET properties of potential drugs. The Log $P$ of complexes 3 and 4 using a modified shake flask method was $0.97 \pm 0.5$ and $2.42 \pm 0.6$ while AlogP98 predictions were 0.8 and 1.5 respectively. These values are within the ideal lipophilicity range of $0 \geq 3$, unlike $\log P$ values of $<0$ which represents poor lipid bilayer permeability and $>3$ which represents poor aqueous solubility [45]. The slight differences between lipophilicity values obtained by the shake flask method and those from the in silico prediction studies might be as a result of the presence of the gold atom in the complexes which are not included in the ADMET AlogP98 protocol (resulting from the AlogP98 unknowns - Table S3). This is because the program was designed from datasets involving organic molecules [44]. However, this does not seem to have had a

drastic effect on the lipophilicity predictions from $D S^{\circledR}$ Client 2.5 compared to those from the shake flask method. As controls in the in silico assay, the ALogP98 of auranofin and that of the anti-HIV agent nevirapine were also determined and resulted in values of 1.4 and 2.29 respectively (Table S3). These findings were in agreement with the literature 
e.g. auranofin's lipophilicity value was within the ideal range and its use as an orally available RA drug is due to this property [46] while nevirapine's ability to cross the blood brain barrier is also ascribed to its lipophilic nature [47]. These findings therefore validate the in silico predictions for the complexes. Details for other drug-like predictions that were obtained with the in silico ADMET protocol are provided in the supplementary section (Table S3).

\section{CONCLUSIONS}

Four new bis(thiosemicarbazonate) gold(III) complexes (1-4) were synthesised. All complexes were soluble in DMSO with 3 and $\mathbf{4}$ sparingly soluble in water. The solid state structure of $\mathbf{4}$ confirms that L4 is bound to two iminic nitrogens and two sulfur atoms. The analytical data and spectroscopic properties establish that L1-L3 have similar stoichiometries and structure. Complex 3 inhibited infection of the TZM-bl cell line by $\mathrm{Du} 151.2$ (a dual subtype $\mathrm{C}$ viral isolate) at a non toxic concentration of $12.5 \mu \mathrm{M}$ while complex 4 did so at physiologically relevant cytostatic concentrations. The ability of the compounds to inhibit HIV-1 RT was also investigated and found to be negative. Cytostatic agents generally exert activity through inhibition of enzymes other than RT [13] e.g. RNR [19]. These agents are known for lowering CD4+ expression and T cell proliferation and that was shown here for 4 . Compound 4 decreased CD4+ cell proliferation without negatively affecting cytokine production. The importance of complexation as seen in the antiviral and immune response assays are relevant with respect to $\mathbf{4}$ and not L4. L4 was inactive in the antiviral assay and deleterious in cytokine studies by augmenting TNF- $\alpha$ production. Complexes $\mathbf{3}$ and $\mathbf{4}$ also demonstrated acceptable drug-like properties with lipophilicity values within the ideal range. 
These findings suggest that these novel gold(III) based Tscs compounds have the potential of being part of a virostatic combination with viral inhibitory agents like didanosine with the possibly of circumventing the development of viral resistance which is the current and major shortcoming of HAART.

A notable observation was the identification of the mechanism by which these compounds inhibit viral activity using the RT-CES analysis. These data indicates the importance of monitoring biochemical assays in real time compared to conventional end point assays such as the MTT assay which could be misleading in terms of whether a compound is cytotoxic or cytostatic.

Ongoing work includes confirming RNR inhibition as the cause of the observed cytostatic behaviour as well as combining these Tscs compounds with antiviral agents which should hopefully result in a synergistic effect both in antiviral activity and in improving immune responses. Additionally, complex 4 (and possibly 1-3) could have anti-cancer abilities (resulting from their cytostatic nature) since gold(III) complexes are known to possess anti-cancer activities [48, 49].

\section{ABBREVIATIONS}

Abbreviation

ACTG

ADMET

AIDS

APC

BD

BMS
Meaning

AIDS Clinical Trials Group

Absorption, Distribution, Metabolism, Excretion, Toxicity

Acquired Immune Deficiency Syndrome

Allophycocyanin

Becton Dickinson

Bristol-Myers Squibb 
$\mathrm{CC}_{50}$

CCR5

CD3+

CD4+

CD8+

CFSE

$\mathrm{Cl}$

CTL

CXCR4

DMEM

DNA

dNTP

DS

FITC

FTIR

HAART

$\mathrm{HU}$

$\mathrm{IC}_{50}$

IFN-Y

IR

MTT

NMR

PBMCs

PE

PerCp-Cy
Cytotoxic Concentration 50\%

Chemokine Receptor 5

Cluster of Differentiation 3 Positive

Cluster of Differentiation 4 Positive

Cluster of Differentiation 8 Positive

CarboxyFlourescein Succinimidyl Ester

Cell Index

Cytotoxic T Lymphocyte

CXC Chemokine Receptor 4

Dulbecco's Modified Essential Medium

Deoxyribonucleic Acid

Deoxynucleotide Triphosphates

Discovery Studio

Flourescein Isothiocyanate

Fourier Transform Infrared

Highly Active Antiretroviral Therapy

Hyrdoxyurea

Inhibitory Concentration $50 \%$

Interferon gamma

Infrared

3-(4,5-dimethylthiazol-2-yl)-2,5-diphenyltetrazolium bromide

Nuclear Magnetic Resonance

Peripheral Blood Mononuclear Cells

Phycoerythrin

Peridinin Chlorophyll Protein-Cyanin 


$\begin{array}{ll}\text { PHA-P } & \text { Phytohemagglutinin-Protein } \\ \text { PI } & \text { Propidium lodide } \\ \text { RA } & \text { Rheumatoid Arthritis } \\ \text { RIGHT } & \text { Research Institute for Genetic and Human Therapy } \\ \text { RNR } & \text { Ribonucleotide Reductase } \\ \text { RT-CES } & \text { Real Time Cell Electronic Sensing } \\ \text { Th } & \text { Thelper } \\ \text { TNF- } \alpha & \text { Tumour Necrosis Factor alpha } \\ \text { Tscs } & \text { Thiosemicarbazones }\end{array}$

\section{ACKNOWLEDGEMENTS}

The authors would like to thank AuTEK Biomed (Mintek and Harmony) and the University of Pretoria for financial support. Additional financial support for this work was provided by L'Oréal and UNESCO as well as the South African National Research Foundation. The authors would also like to thank Frederik H. Kriel of the AuTEK Biomed Team, for his contribution towards the conceptualization of complex design; and David Liles of the University of Pretoria for his help with crystallography.

\section{CONFLICT OF INTERESTS}

The authors declare that they have no competing interests.

\section{AUTHOR'S CONTRIBUTION}

PF was responsible for the biological section of the project while FKK was responsible for the chemistry. DM, the research leader of the study supervised all aspects of the work. All authors read and approved the final manuscript. 


\section{REFERENCES}

[1] V.A. Johnson, F. Brun-Vezinet, B. Clotet, B. Conway, D.R. Kuritzkes, D. Pillay, J.

Schapiro, A. Telenti, D. Richman, Top. HIV. Med. 13 (2005) 51-57.

[2] S.P. Fricker, Gold Bulletin. 29 (1996) 53-60.

[3] G.D. Champion, G.G. Graham, J.B. Ziegler, Baillieres Clin. Rheumatol. 4 (1990) 491534.

[4] P.N. Fonteh, F.K. Keter, D. Meyer, Biometals. 23 (2010) 185-196.

[5] H. Beraldo, D. Gambino, Mini Rev. Med. Chem. 4 (2004) 31-39.

[6] W. Hernandeza, J. Paz, A. Vaisberg, E. Spodine, R. Richter, L. Beyer, Bioinorg Chem. Appl. 2008:690952 Epub. (2009) 690952.

[7] V. Mishra, S.N. Pandeya, C. Pannecouque, M. Witvrouw, E. De Clercq, Arch. Pharm. (Weinheim). 335 (2002) 183-186.

[8] J. Easmon, G. Heinisch, W. Holzer, B. Rosenwirth, J. Med. Chem. 35 (1992) 32883296.

[9] D. Hamre, J. Bernstein, R. Donovick, J. Bacteriol. 59 (1950) 675-680.

[10] P.N. Fonteh, F.K. Keter, D. Meyer, I.A. Guzei, J. Darkwa, J. Inorg. Biochem. 103 (2009) 190-194.

[11] R.W. Sun, W.Y. Yu, H. Sun, C.M. Che, Chembiochem. 5 (2004) 1293-1298.

[12] S.N. Pandeya, D. Sririam, G. Nath, E. DeClercq, Eur. J. Pharm. Sci. 9 (1999) 25-31 [13] F. Lori, A. Foli, A. Groff, L. Lova, L. Whitman, N. Bakare, R.B. Pollard, J. Lisziewicz, AIDS. 19 (2005) 1173-1181.

[14] F. Lori, A.G. Malykh, A. Foli, R. Maserati, A. De Antoni, L. Minoli, D. Padrini, A.

Degli Antoni, E. Barchi, H. Jessen, M.A. Wainberg, R.C. Gallo, J. Lisziewicz, AIDS Res. Hum. Retroviruses. 13 (1997) 1403-1409.

[15] I. Frank, J. Biol. Regul. Homeost. Agents. 13 (1999) 186-191. 
[16] O.T. Rutschmann, M. Opravil, A. Iten, R. Malinverni, P.L. Vernazza, H.C. Bucher, E. Bernasconi, P. Sudre, D. Leduc, S. Yerly, L.H. Perrin, B. Hirschel, AIDS. 12 (1998) F717.

[17] R.J. De Boer, A.S. Perelson, J. Theor. Biol. 190 (1998) 201-214.

[18] L.M. Kelly, J. Lisziewicz, F. Lori, Curr. Pharm. Des. 10 (2004) 4103-4120.

[19] F. Lori, A. Foli, L.M. Kelly, J. Lisziewicz, Curr. Med. Chem. 14 (2007) 233-241.

[20] F. Lori, H. Jessen, J. Lieberman, M. Clerici, C. Tinelli, J. Lisziewicz, AIDS Res. Hum. Retroviruses. 15 (1999) 619-624.

[21] A. Meyerhans, J.P. Vartanian, C. Hultgren, U. Plikat, A. Karlsson, L. Wang, S. Eriksson, S. Wain-Hobson, J. Virol. 68 (1994) 535-540.

[22] F. Lori, A. Malykh, A. Cara, D. Sun, J.N. Weinstein, J. Lisziewicz, R.C. Gallo, Science. 266 (1994) 801-805.

[23] C.N. Mayhew, R. Sumpter, M. Inayat, M. Cibull, J.D. Phillips, H.L. Elford, V.S. Gallicchio, Antiviral Res. 65 (2005) 13-22.

[24] C.L. Clouser, S.E. Patterson, L.M. Mansky, J. Virol. 84 (2010) 9301-9309.

[25] J. Marinello, C. Marchand, B.T. Mott, A. Bain, C.J. Thomas, Y. Pommier, Biochemistry. 47 (2008) 9345-9354.

[26] F. Lori, AIDS. 13 (1999) 1433-1442.

[27] B.P. Block, Inorg. Synth. 4(1953) 14-17.

[28] D.X. West, J.S. Ives, G.A. Bain, A.E. Liberta, J. Valdés-Martínez, K.H. Ebert, S. Hernández-Ortega, Polyhedron. 16 (1997) 1895-1905.

[29] E.J. Platt, K. Wehrly, S.E. Kuhmann, B. Chesebro, D. Kabat, J. Virol. 72 (1998) 2855-2864.

[30] D.C. Montefiori, In: J.E Coligan, A.M. Kruisbeek, D.H. Margulies, E.M. Shevach, W. Strober, R.Coico (Ed.), Evaluating Neutralizing Antibodies Against HIV, SIV and SHIV in 
Luciferase Reporter Gene Assays. Current Protocols in Immunology, John Wiley and Sons, New York, 2004, 12.11.1-12.11.15.

[31] M. Coetzer, T. Cilliers, M. Papathanasopoulos, G. Ramjee, S.A. Karim, C.

Williamson, L. Morris, AIDS Res. Hum. Retroviruses. 23 (2007) 316-321.

[32] J.M. Boyd, L. Huang, L. Xie, B. Moe, S. Gabos, X.F. Li, Anal. Chim. Acta. 615 (2008) 80-87.

[33] J.Z. Xing, L. Zhu, S. Gabos, L. Xie, Toxicol. In. Vitro. 20 (2006) 995-1004.

[34] J.Z. Xing, L. Zhu, J.A. Jackson, S. Gabos, X.J. Sun, X.B. Wang, X. Xu, Chem. Res. Toxicol. 18 (2005) 154-161.

[35] J. Lašt'ovička, V. Budisky, R. Špíšek, J. Bartůňkova, Cell. Immunol. 259 (2009) 7985.

[36] L.F. Yousif, K.M. Stewart, K.L. Horton, S.O. Kelley, Chembiochem. 10 (2009) 20812088.

[37] B.N. Bottenus, P. Kan, T. Jenkins, B. Ballard, T.L. Rold, C. Barnes, C. Cutler, T.J. Hoffman, M.A. Green, S.S. Jurisson, Nucl. Med. Biol. 37 (2010) 41-49.

[38] K. Haselsberger, D.C. Peterson, D.G. Thomas, J.L. Darling, Anticancer Drugs. 7 (1996) 331-338.

[39] F. Denizot, R. Lang, J. Immunol. Methods. 89 (1986) 271-277.

[40] T. Spector, T.E. Jones, J. Biol. Chem. 260 (1985) 8694-8697.

[41] G. Caso, P.J. Garlick, M.C. Gelato, M.A. McNurlan, Clin. Sci. (Lond). 101 (2001) 583-589.

[42] L. Lova, A. Groff, E. Ravot, G. Comolli, J. Xu, L. Whitman, M. Lewis, A. Foli, J.

Lisziewicz, F. Lori, AIDS 19 (2005) 137-144.

[43] R.S. Veazey, I.C. Tham, K.G. Mansfield, M. DeMaria, A.E. Forand, D.E. Shvetz, L.V. Chalifoux, P.K. Sehgal, A.A. Lackner, J. Virol. 74 (2000) 57-64. 
[44] A.K. Ghose, V.N. Viswanadhan, J.J. Wendoloski, J. Phys. Chem. A 102 (1998) $3762-3772$

[45] H. Kerns , L. Di, Drug-like properties: concepts, structure design and methods, from ADME to toxicity optimisation. Academic Press, Boston, 2008.

[46] D.L. Shapiro, J.R. Masci, J. Rheumatol. 23 (1996) 1818-1820.

[47] S.L. Glynn, M. Yazdanian, J. Pharm. Sci. 87 (1998) 306-310.

[48] A. Casini, C. Hartinger, C. Gabbiani, E. Mini, P.J. Dyson, B.K. Keppler, L. Messori, J. Inorg. Biochem. 102 (2008) 564-575.

[49] C-M. Che, R.W-Y. Sun, W-Y. Yu, C-B. Ko, N. Zhu, H. Sun, Chem. Commun. 14 (2003) 1718-1719.

\section{CAPTIONS FOR FIGURES}

Fig. 1: Bis(thiosemicarbazones) L1-L4 and their respective complexes 1-4.

Fig. 2: Solid state structure of 4 . The bond lengths and bond angles are not discussed owing to poor crystallographic data. The Ortep diagram is presented for the purposes of showing the connectivity of the atoms.

Fig. 3: The effect of complexes (1-4) on the viability and infectivity of TZM-bl cells after $48 \mathrm{~h}$ of incubation. Inhibition of infectivity of TZM-bl cells by DU151.2 is represented on the primary y axis while viability using MTT is represented on the secondary y axis. Toxicity appeared to account for the observed increasing viral inhibition by the complexes except in the case of complex 3 (95\% inhibition and $67 \%$ viability at 12.5 $\mu \mathrm{M})$. 
Fig. 4: The effect of complex $\mathbf{4}$ and ligand L4 on the proliferation of TZM-bl cells using RT-CES analysis. The cells were seeded into an E-plate and allowed to adhere for at least $20 \mathrm{~h}$ followed by treatment with three different concentrations $(0.1,5$ and $10 \mu \mathrm{M})$ of 4 and L4. Normalized $\mathrm{Cl}$ is plotted on the y-axis against time (h) on the $\mathrm{x}$-axis. Complex 4 (a) displays a dose dependent cytostatic tendency while L4 (b) does not when compared to the vehicle control. Auranofin $(10 \mu \mathrm{M})$ was used as a positive control for cell death. The data was normalized against the time point where $\mathbf{4}$ (a) and L4 (b) were added to the cells i.e. $20 \mathrm{~h}$.

Fig. 5: The effect of the compounds on the proliferation of PBMCs after $72 \mathrm{~h}$ of treatment. Cell proliferation was monitored using the CFSE cell proliferation dye and flow cytometry. The seven parts from top to bottom in each of the seven bars are for generations $0-6$. Complexes 3 and 4 have the highest percentage of cells in generation 1 and none in generation 6 , depicting the cytostatic nature of these complexes compared to untreated cells.

Fig. 6: The effect of $4(5 \mu \mathrm{M})$ on the expression of CD4+ cells from PBMCs. Box and whisker plots show median and range of CD4+ cell expression in PBMCs cultured in the presence of 4 for $24 \mathrm{~h}$. Bars show $25^{\text {th }}$ and $75^{\text {th }}$ percentile. Statistical analysis (Wilcoxon matched-pairs signed rank test) revealed significant difference $(p=0.0049)$ in the frequency of cells expressing the CD4+ marker from PBMCs obtained from HIV infected donors after treatment with 4 compared to untreated cells. This suppressing effect of 4 makes it a candidate for drug combinations that includes compounds directly inhibiting virus for HIV treatment. L2, L4 and $\mathbf{2}$ do not have a significant effect on the expression of CD4+ cells. 


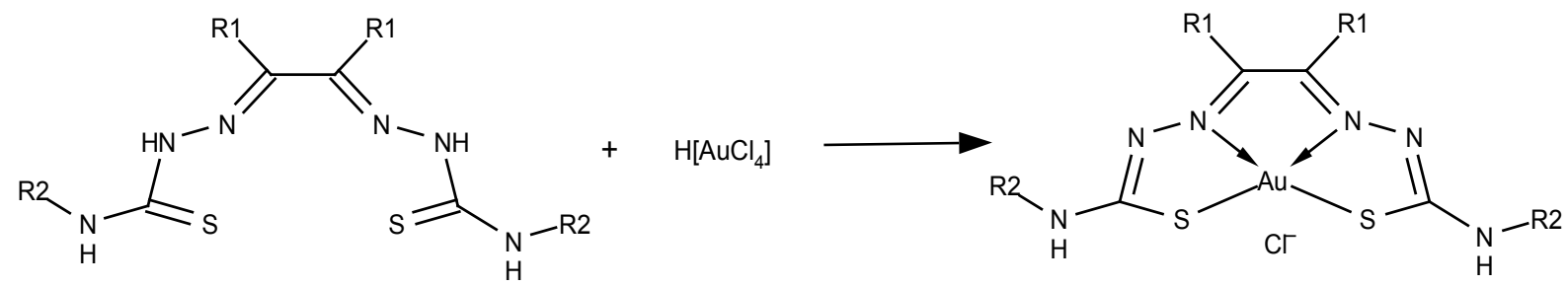

$\mathrm{R} 1=\mathrm{H}, \mathrm{R} 2=\mathrm{Me}(\mathbf{1}) ; \mathrm{R} 1=\mathrm{H}, \mathrm{R} 2=\mathrm{Et}(\mathbf{2})$

$\mathrm{R} 1=\mathrm{Me}, \mathrm{R} 2=\mathrm{Me}(\mathbf{3}) ; \mathrm{R} 1=\mathrm{Me}, \mathrm{R} 2=\mathrm{Et}(\mathbf{4})$

Fig. 1

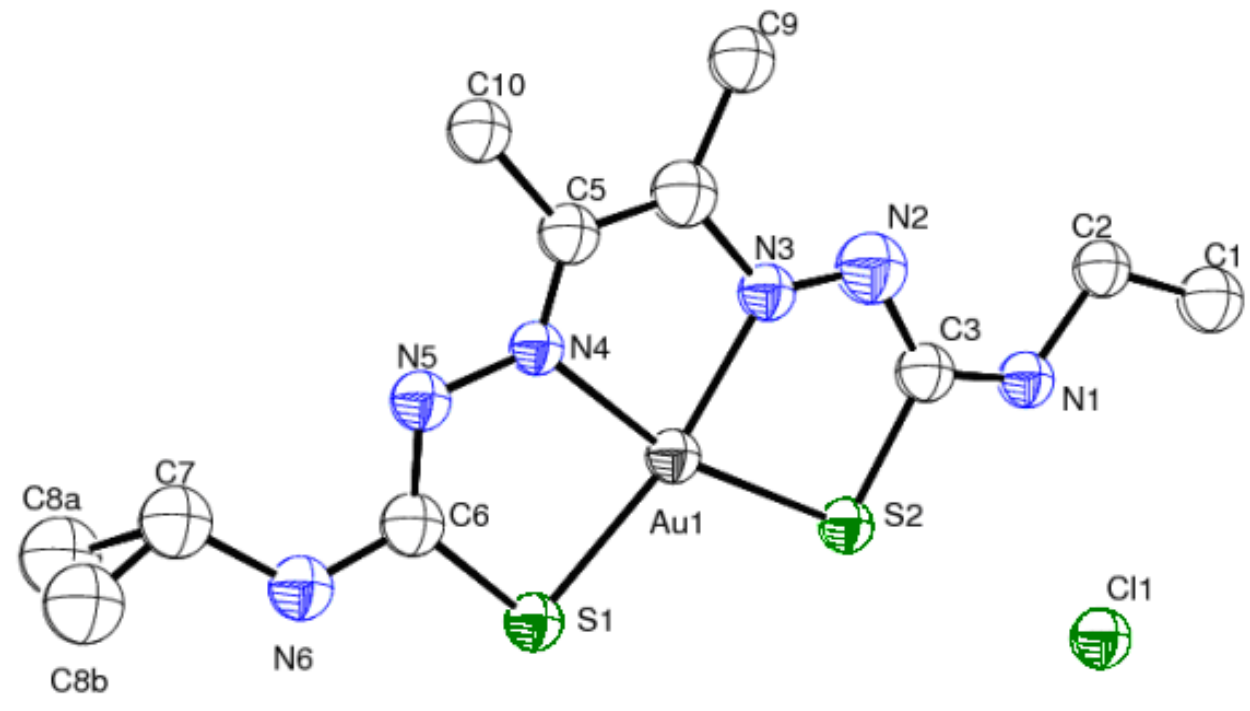

Fig. 2 

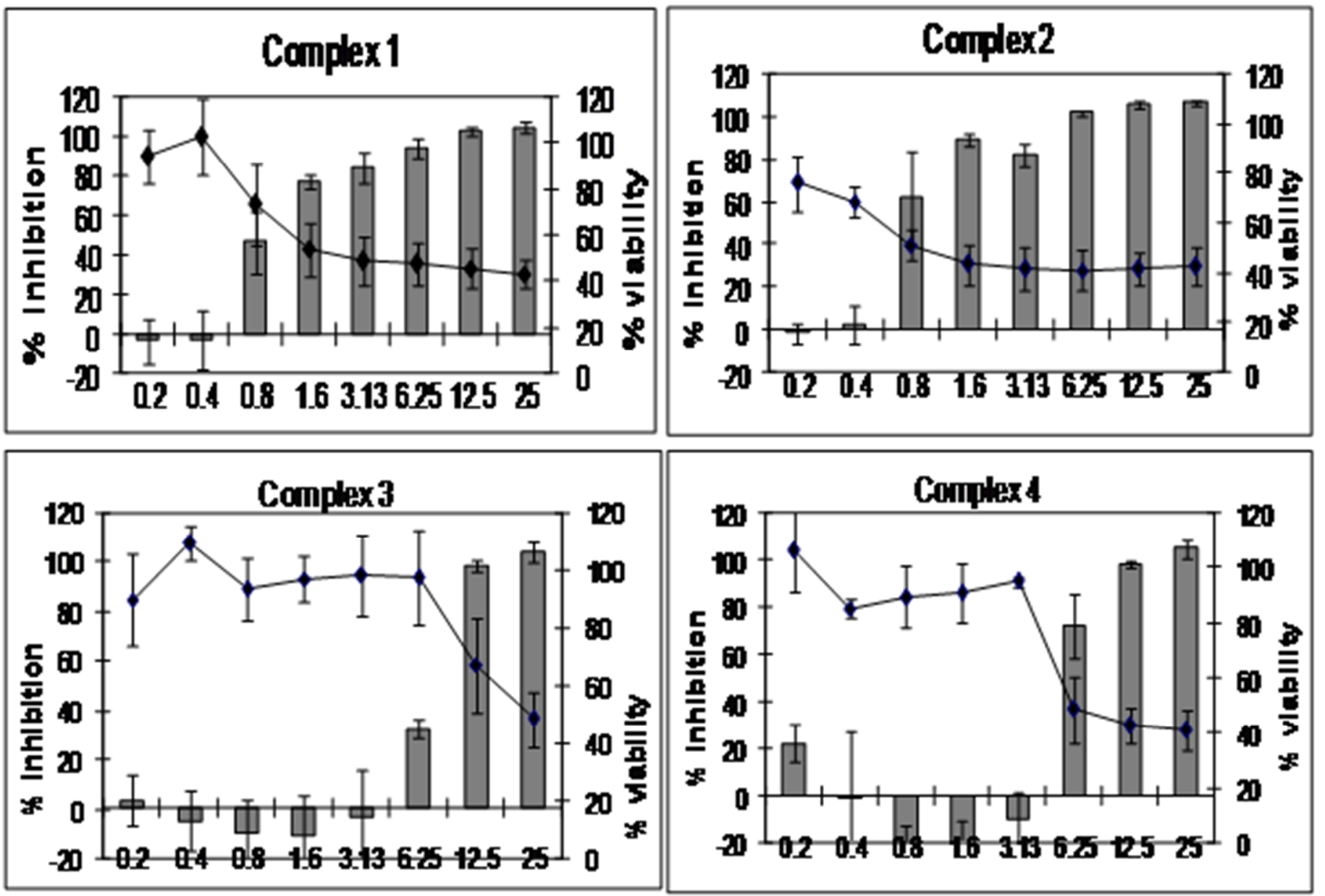

Concentration (pM)

Fig. 3 

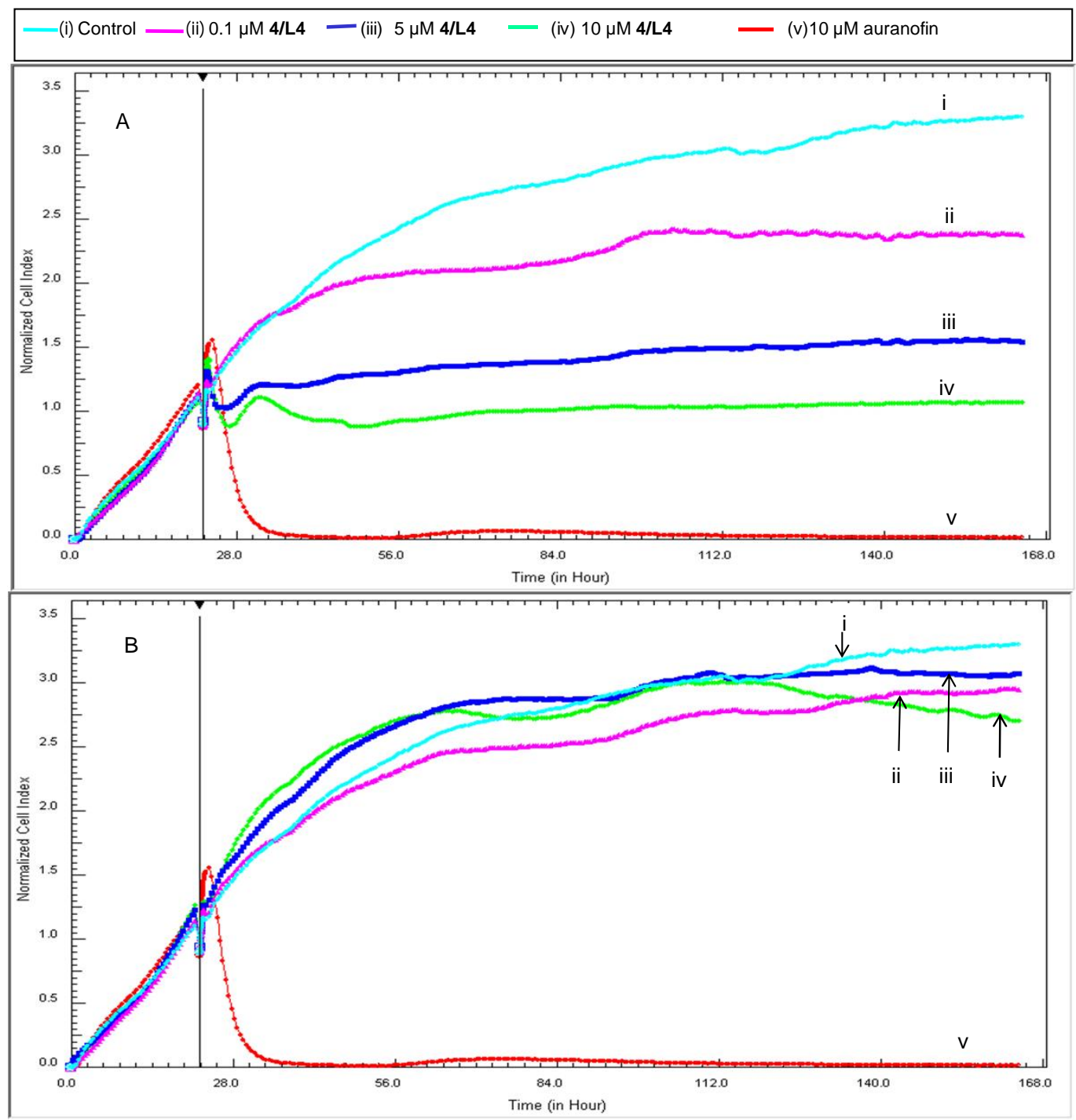

Fig. 4 


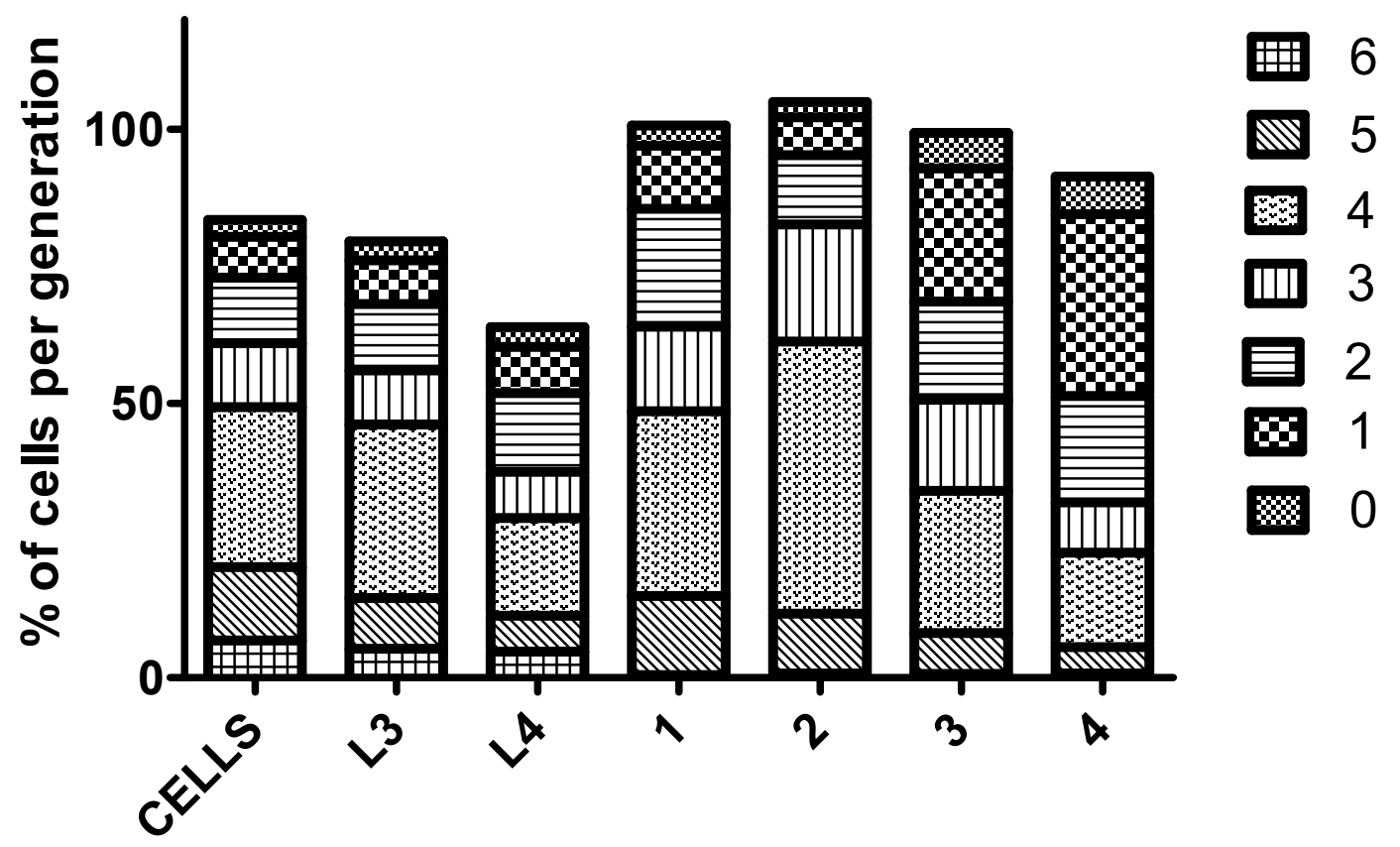

Fig. 5

HIV+CD4+PBMCs

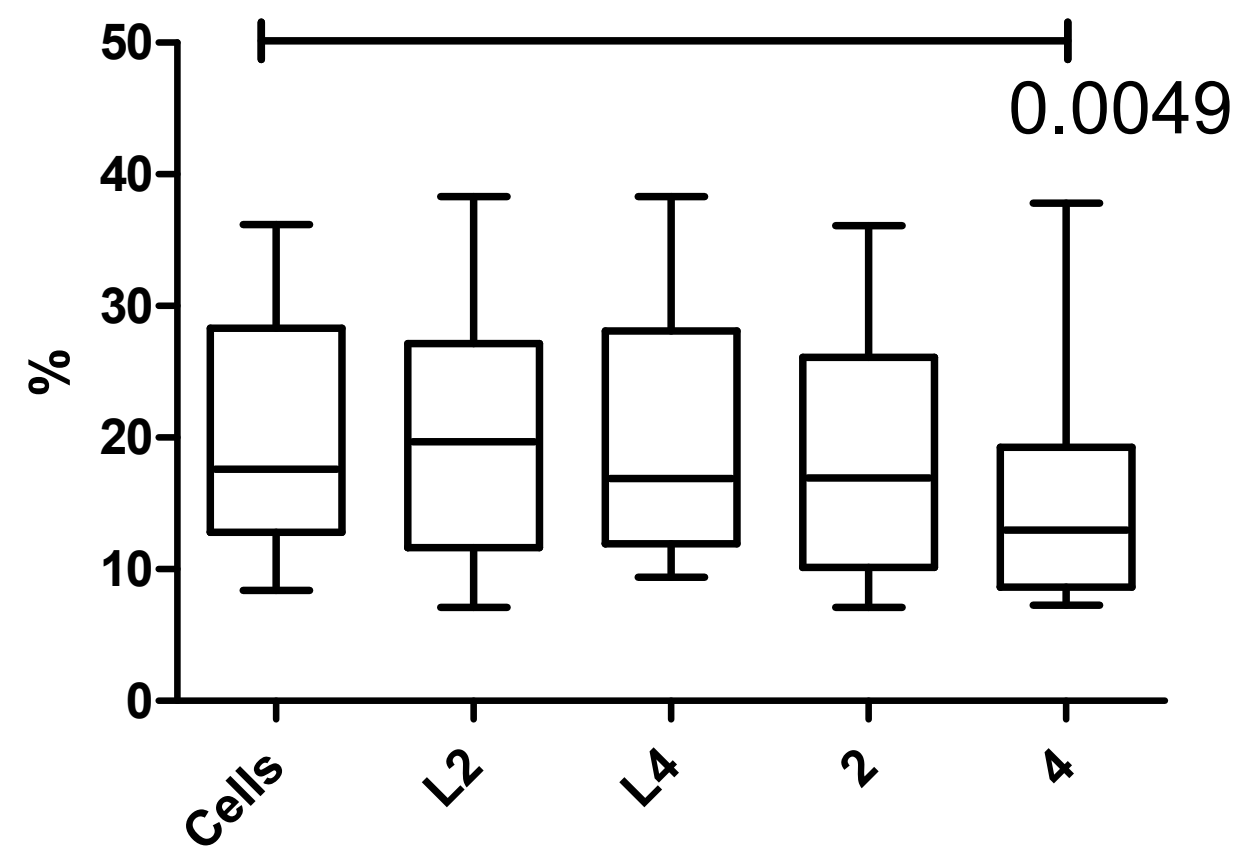

Fig. 6 
GRAPHICAL ABSTRACT

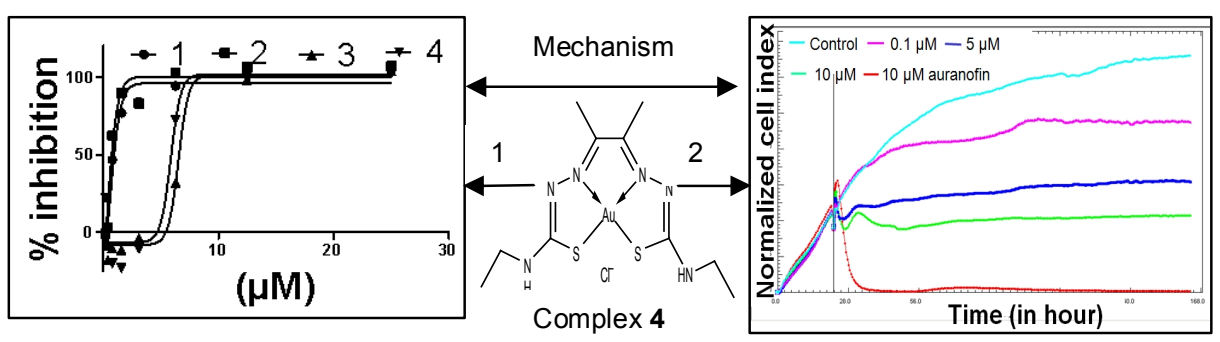

$1=$ Viral infectivity inhibition, $2=$ cytostasis

\section{GRAPHICAL ABSTRACT SYNOPSIS}

Viral infectivity inhibition at cytostatic concentrations by two of four newly synthesized gold(III) thiosemicarbazonate compounds is due to the effect of the compounds on host cell mechanisms rather than a direct anti-viral ability. These findings suggest the incorporation of these novel compounds in an emerging class of antiviral agents known as virostatics which promise better resistance profiles.

Inhibition of viral infectivity at cytostatic concentrations by two of four gold(III) thiosemicarbazonate compounds is due to compound effects on host cell mechanisms rather than direct anti-viral ability. These findings suggest the incorporation of these novel compounds in the emerging antiviral combination called virostatics which promise better resistance profiles. 